\title{
Determinants of Male Adolescents Smoking Behavior in Indonesia using Negative Binomial Regression*
}

\author{
Angel Zushelma Hartono ${ }^{1}$ and Siskarossa Ika Oktora ${ }^{2 \ddagger}$
}

\author{
1,2Politeknik Statistika STIS, Indonesia \\ ${ }^{\ddagger}$ corresponding author: siskarossa@stis.ac.id
}

Copyright $@ 2021$ Angel Zushelma Hartono and Siskarossa lka Oktora. This is an open-access article distributed under the Creative Commons Attribution License, which permits unrestricted use, distribution, and reproduction in any medium, provided the original work is properly cited.

\begin{abstract}
Adolescent smoking habits have become the Ministry of Health's major program associated with tobacco consumption. In 2016, the prevalence of adolescent smoking aged $10-18$ years reached $8.8 \%$ and were rate increasingly against the Strategic Planning Ministry of Health 2015-2019 target to lower adolescent smoking prevalence to $5.4 \%$. Male adolescents consuming cigarettes are higher than females. Whereas, high consumption of cigarettes in men will increase the risk of impotence and decrease reproductive health quality to affect future generations' quality. This study aims to determine the general picture of smoking behavior in Indonesia's male adolescent in 2018 and any variables that affect the number of cigarettes consumed. The analytical method used is Poisson Regression and Negative Binomial Regression. The data source used is raw data Riskesdas 2018 with the unit of analysis are male adolescent smokers aged 10-18 years. Research indicates that most male adolescents are light smokers. Heavy smokers were dominated by older age, living in a rural area, poorly educated, employed, lived with a household head who was a smoker, and had low education. Age, location of residence, education level, working status, smoking status, and household head education level significantly affect male adolescents' smoking behavior.
\end{abstract}

Keywords: male adolescent, negative binomial regression, poisson regression, smoking behavior.

\footnotetext{
${ }^{*}$ Received: Jan 2021; Reviewed: Mar 2021; Published: Mar 2021
} 


\section{Introduction}

The third purpose of Sustainable Development Goals (SDGs) is to ensure healthy lives and promote well-being for all ages. One of the targets is to reduce one-third of all premature deaths from non-communicable diseases (NCD). Smoking behavior is one of the main risk factors for NCD. According to the World Health Organization (WHO), smoking is one of the world's largest health threats. The smoke of cigarettes contains over 7,000 chemicals, of which 69 are carcinogenic. The primary components of cigarettes include nicotine that makes it addictive, carcinogenic tar, and carbon monoxide (CO) that lower oxygen levels in the blood (Kemenkes, 2013). Each year, more than 8 million deaths worldwide are caused by cigarettes, 7 million deaths from direct smoking, and about 1.2 million deaths from cigarette smoke (WHO, 2020). By 2030, cigarette-related deaths are expected to reach 10 million annually, with more than $70 \%$ of deaths occurring in developing countries (Kemenkes, 2015).

Indonesia was the third-highest number of smokers in the world after China and also India(Kemenkes, 2015). The Indonesian Basic Health Research (Riskesdas) 2013 indicates that the proportion of people 15 years and up who use tobacco, whether smoking or chewing, tend to increase from $34.7 \%$ (2010) to $36.3 \%$ with an average number of cigarette consumed daily is 12.3 or equivalent to a pack of cigarettes.

A shift in smoking habits begins in adolescence(Komasari \& Helmi, 2000). Based on Riskesdas of 2010-2013, the age for smoking has been dominated by age 10-19. The proportion of beginner smokers age 15-19 increased from 43.2\% in 2010 to 55.4 $\%$ in 2013 (Kemenkes, 2013).

Adolescent smoking habits have become the Ministry of Health's major program associated with tobacco consumption(BPPK, 2016). The results of Riskesdas 2013 show that the prevalence of smoking in $10-18$ years was $7.2 \%$. Then, based on Sirkesnas 2016, the prevalence of adolescent smokers was $8.8 \%$. It is rated to have been further removed from the Strategic Planning Ministry of Health 2015-2019 target to lower adolescent smokers' prevalence to $5.4 \%$.

Male adolescents smoke more than females. Men tend to start smoking at a young age, while women at an older age. An increase in men who began smoking occurred in adolescence and productive age, especially 15-19 (BPPK, 2014). Male adolescent believes that cigarettes are a symbol of power, masculinity, and manhood. They do not want to be seen as a coward, so they dare to take a risk to smoke more than females (Wijayanti \& Dewi, 2017).

Almost $49.8 \%$ of male adolescents consume $11-20$ cigarettes a day, and $5.6 \%$ consume more than 20 cigarettes a day (Sirait et al., 2002). Furthermore, according to the Indonesian Demographic and Health Survey (IDHS), the proportion of male adolescents who consumed more than ten cigarettes a day increased from $38 \%$ in 2012 to $50 \%$ in 2017 . Whereas, high consumption of cigarettes in men will increase the risk of impotence by $50 \%$. It also lowers the level of reproductive health to affect the next generation (Suhta, 2018).

Smoking causes the lousy quality of the generation and poses a significant threat to the Indonesian demographics bonus's growth and success. Based on the description, smoking behavior in this study focuses on the number of cigarettes 
consumed by male adolescents. This study aims to find out the pattern and analyze the determinants of Indonesian male adolescents' smoking behavior in 2018.

\section{Method}

\section{$2.1 \quad$ Data Source}

Adolescents are people who are in a transition from childhood to adulthood. Ministry of Health Regulation No. 25 of 2014 concerning Child Health Effort, adolescents, include 10-18 years of age. Adolescence is the time of identity seeking. In this period, adolescents do not want to be called kids and try to behave like adults (Tristanti, 2016). Curiosity and a desire to try new things cause adolescents to begin engaging in various risky behaviors such as smoking behavior(Cahyo et al., 2012).

Smoking behavior is an activity aimed at burning cigarettes or tobacco in a cigarette pipe and then being sucked to get the effect of the substance contained (Tristanti, 2016). Cigarette in Government Regulation No. 109 of 2012 concerning Materials that Contain Addictive Substances in Tobacco Products in the Interests of Health is one of the tobacco products produced from Nicotiana tabacum, Nicotiana rustica, and other species containing nicotine and tar, with or without added ingredient. Classified smokers into three categories by cigarette consumption (Wulandari et al., 2017). Light smokers consume about 1-24 cigarettes a week, moderate smokers consume about 25-99 cigarettes a week, and heavy smokers consume more than 99 cigarettes a week.

Many factors influence adolescent smoking behavior. According to Kurt Lewin in Komasari and Helmi (2000), smoking behavior is influenced not only by themself but also by the environment. Adolescents, age 10-18 based on Riskesdas 2013, show that gender, age, economic status, and education level affect adolescent smoking behavior (Kusumawardani et al., 2018). Research using Zero Inflated Poisson (ZIP) regression shows that age, employment status, and education level affect the consumption of cigarettes (Wulandari et al., 2017).

The existing use of cigarettes and other tobacco is higher in rural areas than the urban area (Pesko \& Robarts, 2017). The family is one of the factors that influence adolescent smoking behavior (Sutha, 2016). Living with parents who smoke tend to make adolescents become active smokers. Moreover, parental education also affects adolescents smoking behavior. A lower level of parental education makes the prevalence of adolescents smoking behavior increase (Geckova et al., 2002).

This study included all Indonesian provinces in 2018, with the analysis unit, which is male adolescent smokers age 10-18 and unmarried. We used secondary data from Riskesdas 2018. The dependent variable is the number of cigarettes consumed in weeks, while the independent variables are male adolescent characteristics, including age, location of residence, education level, employment status. This study also uses household head characteristics, including smoking status and education level, as independent variables. The respondents are 10-18 years old adolescents, according to the Ministry of Health Regulation No. 25 of 2014 concerning Child Health Effort. The location of residence is categorized as rural and urban areas. The education level of male adolescents and household heads are classified as not in school yet, not 
complete elementary school, completed elementary school, completed junior high school, and completed senior high school or higher. The working status is categorized as employed and unemployed. The household head smoking status is categorized as smoking and not smoking.

\subsection{Research Method}

The analysis methods used are descriptive and inferential analysis. The descriptive analysis aims to describe male adolescent smoking behavior in general based on the number of cigarette consumption. The purpose of the inferential analysis is to determine variables that influence male adolescent smoking behavior. The dependent variable is discrete data (count data), so the appropriate regression to use is Poisson Regression and Negative Binomial Regression to resolve overdispersion from the Poisson Regression.

Poisson regression explains the relationship between dependent variables, which are count data and independent variables. An assumption in this regression model is the dependent variable has equal mean and variance and is called equidispersion (Agresti, 2018).

$$
E(y)=\mu \text { and } \operatorname{Var}(y)=\mu
$$

Poisson regression is a log-linear regression model that applies the Generalized Linear Model (GLM). In GLM, a log link function will connect the mean of the dependent variable and linear predictors (Montgomery et al., 2012):

$$
g\left(\mu_{i}\right)=\ln \left(\mu_{i}\right)=\beta_{0}+\beta_{1} x_{1 i}+\beta_{2} x_{2 i}+\cdots+\beta_{p i} x_{p i}=x_{i}^{T} \beta
$$

The model of Poisson regression with a log link function is (Montgomery et al., 2012):

$$
\mu_{i}=\exp \left(\beta_{0}+\beta_{1} x_{1 i}+\beta_{2} x_{2 i}+\cdots+\beta_{p i} x_{p i}\right)=e^{x_{i}^{T} \beta}
$$

The parameter estimate in Poisson regression use the Maximum Likelihood Estimator (MLE) method with log-likelihood function is (Montgomery et al., 2012):

$$
L(y ; \beta)=\prod_{i=1}^{n} f_{i}\left(y_{i}\right)=\prod_{i=1}^{n} \frac{e^{-\mu_{i}} \mu_{i} y_{i}}{y_{i} !}=\frac{\prod_{i=1}^{n} \mu_{i}^{y_{i}} \exp \left(-\sum_{i=1}^{n} \mu_{i}\right)}{\prod_{i=1}^{n} y_{i} !}
$$

With $\mu_{i}=\exp \left(x_{i}^{T} \beta\right)$, then the log-likelihood function is:

$$
\ln L(y ; \beta)=\sum_{i=1}^{n} y_{i}\left(x_{i}^{T} \beta\right)-\sum_{i=1}^{n} e^{\left(x_{i}^{T} \beta\right)}-\sum_{i=1}^{n} \ln \left(y_{i} !\right)
$$

Next, parameter $(\hat{\beta})$ can be estimated by maximizing the log-likelihood function in equation (4).

Overdispersion is a violation of equidispersion whereby variance values are higher than mean. It will cause the result's standard error valueresult's standard error value 
to become underestimated from the parameter, so the estimation parameter that should not be significant becomes significant (Hilbe, 2011). To detect overdispersion in the Poisson regression model, the value of Deviance/df and Pearson Chi-square/df (Yandira, 2019).

$$
\frac{D}{d f} \text { dengan } D=2 \sum_{i=1}^{n}\left(y_{i} \log \frac{y_{i}}{\mu_{i}}\right) \quad \text { and } \quad \frac{\chi^{2}}{d f} \text { dengan } \chi^{2}=\sum_{i=1}^{n} \frac{\left(y_{i}-\mu_{i}\right)^{2}}{\sigma_{i}}
$$

Overdispersion is when the value is more than 1 . The alternative to handling the overdispersion is by replacing the dependent variable's distribution assumption from Poisson distribution to Negative Binomial distribution (Utami, 2013).

Negative Binomial regression has no assumption of equidispersion. So the value of variance can be higher than the mean (Agresti, 2018). The Negative Binomial distribution is a mixture of Poisson-gamma distribution, so that value of mean and variance is (Hilbe, 2011):

where $\alpha$ is the dispersion parameter.

$$
E(y)=\mu \text { dan } \operatorname{Var}(y)=\mu+\alpha \mu^{2}
$$

The model of negative binomial regression with the log link function is:

$$
\mu_{i}=\exp \left(\beta_{0}+\beta_{1} x_{1 i}+\beta_{2} x_{2 i}+\cdots+\beta_{p i} x_{p i}\right)=e^{x_{i}^{T} \beta}
$$

Parameter estimate in negative binomial regression use Maximum Likelihood Estimator (MLE) method with likelihood function is (Hilbe, 2011):

$$
L\left(y_{i} ; \alpha, \beta\right)=\prod_{i=1}^{n} \frac{\Gamma\left(y_{i}+1 / \alpha\right)}{\Gamma\left(y_{i}+1\right) \Gamma(1 / \alpha)}\left(\frac{1}{1+\alpha \mu_{i}}\right)^{\frac{1}{\alpha}}\left(1-\frac{1}{1+\alpha \mu_{i}}\right)^{y_{i}}
$$

With $\mu_{i}=\exp \left(x_{i}^{T} \beta\right)$, then log-likelihood function(Hardin et al., 2007):

$$
\begin{aligned}
& \ln L\left(y_{i} ; \alpha, \beta\right) \\
& =\sum_{i=1}^{n}\left\{\begin{array}{c}
y_{i} \ln \left(\frac{\alpha \mu_{i}}{1-\alpha \mu_{i}}\right)-\frac{1}{\alpha} \ln \left[1+\alpha\left(e^{x_{i}^{T} \beta}\right)\right]+\ln \Gamma\left(y_{i}+\alpha^{-1}\right) \\
-\ln \Gamma\left(y_{i}+1\right)-\ln \Gamma\left(\alpha^{-1}\right)
\end{array}\right\}
\end{aligned}
$$

Next, parameters $(\hat{\alpha}, \hat{\beta})$ can be estimated by maximizing the log-likelihood function in equation (7).

In Poisson and Negative Binomial regression, parameter significance uses simultaneous and partial test. Simultaneous testing using the Likelihood Ratio test finds out if there are at least one independent variables that influence the dependent variable with:

$H_{0}: \beta_{1}=\beta_{2}=\ldots=\beta_{k}=0$

$H_{1}$ : at least one $\beta_{j} \neq 0$ with $j=1,2, \ldots, k$

The statistical test is: 


$$
L R=-2 \ln \left[\frac{L_{0}}{L_{1}}\right]=-2\left[\ln \left(L_{0}\right)-\ln \left(L_{1}\right)\right]
$$

with $L_{0}$ is the likelihood value of a model without independent variables, and $L_{1}$ is the likelihood value of a model with independent variables.

The decision of rejecting $\mathrm{H}_{0}$ when the value of $L R>\chi_{\alpha ; k}^{2}$ or $\mathrm{p}$-value $<\alpha$, which means at least one independent variable affects the dependent variable.

Partial testing finds out independent variable which influences the dependent variable using the Wald test:

$\mathrm{H}_{0}: \beta_{j}=0$

$\mathrm{H}_{1}: \beta_{j} \neq 0$

The statistical test is:

$$
W_{j}=\left(\frac{\hat{\beta}_{j}}{S E\left(\hat{\beta}_{j}\right)}\right)^{2}
$$

The decision to reject $\mathrm{H}_{0}$ is when the value of $W_{j}>\chi_{\alpha ; 1}^{2}$ or $\mathrm{p}$-value $<\alpha$, which means each independent variable affects the dependent variable. The steps of inferential analysis in this study are as follows. Firstly, by doing a model check on Poisson regression. Next, testing equidispersion to check whether there is an overdispersion in the Poisson regression model. If there is an overdispersion, then use negative binomial regression. Choose the best model between Poisson regression and Negative Binomial regression using AIC and BIC.

\section{Results and Discussion}

\subsection{Results}

The result of 2018 Riskesdas shows that there were 12,153 male adolescent smokers age $10-18$, of which $56.30 \%$ of them were daily smokers, and the rest were occasional smokers. Based on the number of cigarettes consumed in a week, $53.37 \%$ of the male adolescent was light smokers, about $33.54 \%$ were moderate smokers, and the rest, about $13.09 \%$ who were heavy smokers.

The average number of cigarette consumption by male adolescents in Indonesia in 2018 reached 37.75 cigarettes every week, which means each male adolescent smoked about 37-38 cigarettes every week. The province with the highest average of cigarette consumption was Jambi, with 55.78 cigarettes every week, and the lowest was East Nusa Tenggara, with 24.99 cigarettes every week. Most types of cigarette that consumed by male adolescent was kretek cigarettes at $44.56 \%$.

Based on Table 1, male adolescent smokers increased with the passing of years. Moreover, as they got older, the proportion of light smokers decreased while moderate and heavy smokers increased. Based on residence location, the proportion of light and moderate smokers in urban areas was higher than a rural area. In contrast, the proportion of heavy smokers in rural areas was higher than in urban areas. Based on the education level, male adolescent smokers were dominated by those who had completed junior high school. 
Table 1: The general description of smoking behavior according to independent variables

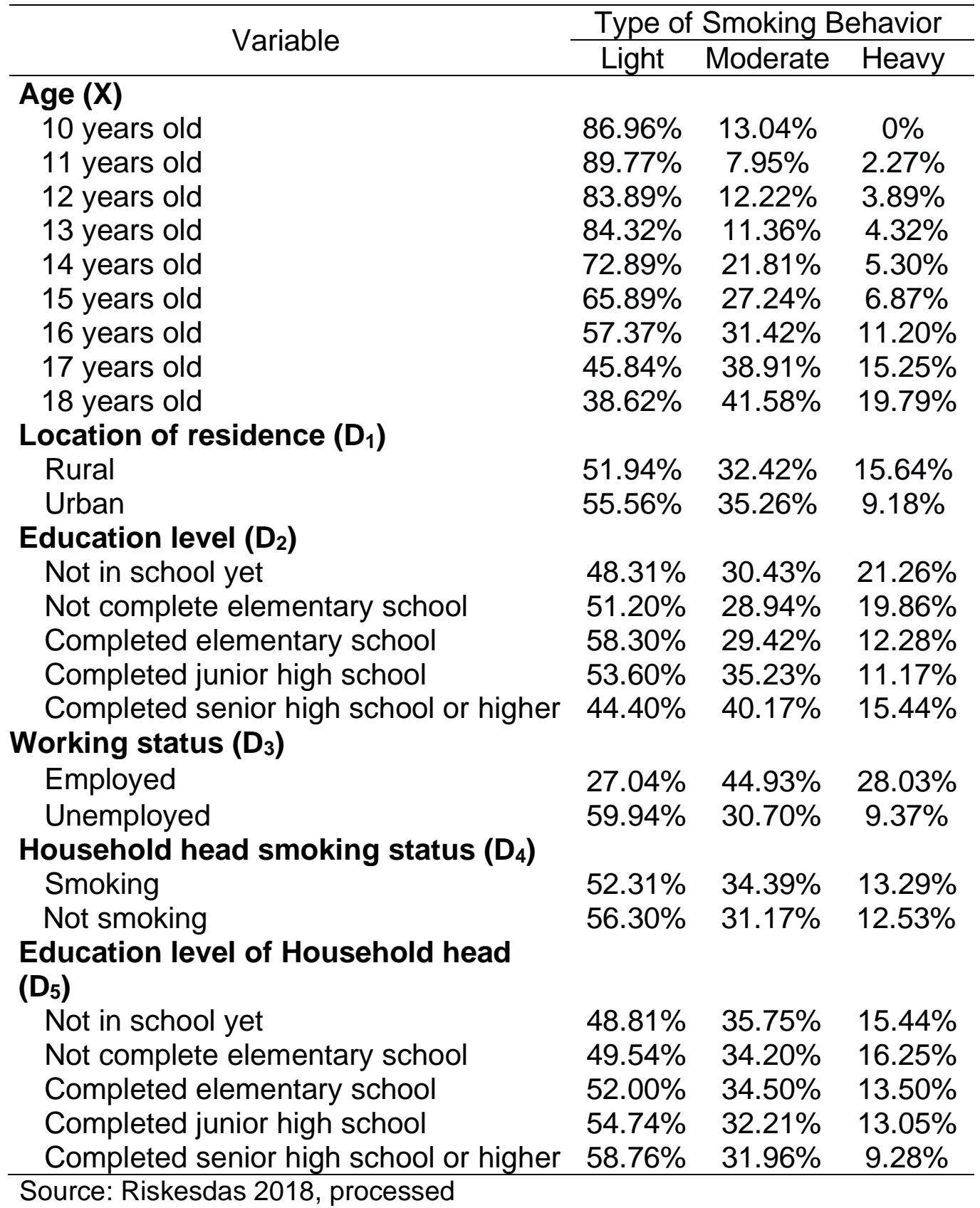

The highest proportion of light smokers were those who had completed elementary school, while the highest proportion of moderate smokers were those who had completed senior high school or higher. The highest proportion of heavy smokers were those who not in school yet. Based on working status, the highest proportion of light smokers were unemployed (have no job) while the highest proportion of moderate and heavy smokers already have a job.

Based on the household head's smoking status, the highest proportion of light smokers lived with a household head who was not smoking. Otherwise, the highest proportion of moderate and heavy smokers lived with a household head who smoked. Based on the household head's education level, male adolescent smokers were 
dominated by those who have a household head who had completed elementary school. The highest proportion of light smokers lived with a household head who had completed senior high school or higher. The highest proportion of moderate smokers lived with a household head who not in school yet, and the highest proportion of heavy smokers lived with households who not completed elementary school.

In Poisson regression, the result of simultaneous testing shows that the value of $\mathrm{LR}=21689125.48$ was higher than $\chi_{0,05 ; 12}^{2}=21.026$, which means at least one independent variable affects the dependent variable at a level of significance $5 \%$. The result of partial testing shows that the value of $W_{j}$ for each independent variable was higher than $\chi_{\alpha ; 1}^{2}$ which means every independent variable affects to dependent variable at a level of significance $5 \%$. The estimation of Poisson regression is shown in Table 2.

Table 2: The result of estimation with Poisson regression

\begin{tabular}{|c|c|c|c|c|}
\hline Variable & B & $\mathrm{RR}$ & SE & $P$-value \\
\hline Age $(X)$ & .224 & 1.251 & .0004 & .000 \\
\hline \multicolumn{5}{|l|}{ Location of residence $\left(D_{1}\right)$} \\
\hline Rural & .127 & 1.135 & .0012 & .000 \\
\hline Urban*) & $0^{\mathrm{a}}$ & & & \\
\hline \multicolumn{5}{|l|}{ Education level $\left(D_{2}\right)$} \\
\hline Not in school yet & .408 & 1.504 & .0053 & .000 \\
\hline lete elementary school & .254 & 1.289 & .0028 & .000 \\
\hline Completed elementary school & 108 & 1.114 & .0021 & .000 \\
\hline Completed junior high school & -.026 & .974 & .0017 & .000 \\
\hline Completed senior high school & $0^{\mathrm{a}}$ & & & \\
\hline \multicolumn{5}{|l|}{ Working status $\left(D_{3}\right)$} \\
\hline Employed & .490 & 1.632 & .0014 & .000 \\
\hline Unemployed*) & $0^{a}$ & & & \\
\hline \multicolumn{5}{|l|}{ Household head smoking status $\left(D_{4}\right)$} \\
\hline Smoking & .013 & 1.013 & .0013 & .000 \\
\hline Not smoking*) & $0^{a}$ & & & \\
\hline \multicolumn{5}{|l|}{ Education level of Household head $\left(D_{5}\right)$} \\
\hline Not in school yet & .082 & 1.086 & .0025 & .000 \\
\hline Not complete elementary school & .147 & 1.158 & .0018 & .000 \\
\hline Comp & .100 & 1.105 & .0015 & .000 \\
\hline Completed junior high school & .087 & 1.091 & .0018 & .000 \\
\hline Completed senior high school or higher ${ }^{*}$ ) & $0^{\mathrm{a}}$ & & & \\
\hline
\end{tabular}

The model of Poisson regression as follows:

$$
\begin{array}{r}
\hat{\mu}=\exp \left(-0.130+0.207 X+0.120 D_{11}+0.267 D_{21}+0.271 D_{22}+0.110 D_{23}-0.026 D_{24}\right. \\
\left.+0.459 D_{31}+0.024 D_{41}+0.049 D_{51}+0.138 D_{52}+0.099 D_{53}+0.074 D_{54}\right)
\end{array}
$$

The equidispersion test result shows that the value of Deviance/df and Pearson Chi-square/df is higher than one, which means there is an overdispersion. This condition makes Poisson regression unsuitable for data. Negative Binomial regression is then used as an alternative model to handle the Poisson regression model's 
overdispersion. In Negative Binomial regression, the simultaneous testing shows that the value of $L R=596679.838$ was higher than $\chi_{0,05 ; 12}^{2}=21.026$, which means at least one independent variable affects the dependent variable at a level of significance $5 \%$. The result of partial testing shows that the value of $W_{j}$ for each independent variable was higher than $\chi_{\alpha ; 1}^{2}$ which means every independent variable affects to dependent variable at a level of significance $5 \%$. The estimation of Negative Binomial regression is shown in Table 3.

Table 3: The estimation result of negative binomial regression.

\begin{tabular}{|c|c|c|c|c|}
\hline Variable & $\mathrm{B}$ & $\mathrm{RR}$ & SE & $P$-value \\
\hline Age $(X)$ & .224 & 1.251 & .0004 & .000 \\
\hline \multicolumn{5}{|l|}{ Location of residence $\left(D_{1}\right)$} \\
\hline Rural & 127 & 1.135 & .0012 & .000 \\
\hline Urban*) & $0^{\mathrm{a}}$ & & & \\
\hline \multicolumn{5}{|l|}{ Education level $\left(D_{2}\right)$} \\
\hline Not in school yet & .408 & 1.504 & .0053 & .000 \\
\hline Not complete elementary school & .254 & 1.289 & .0028 & .000 \\
\hline Completed elementary school & 108 & 1.114 & .0021 & .000 \\
\hline Completed junior high school & -.026 & .974 & .0017 & .000 \\
\hline $\begin{array}{l}\text { Completed senior high school or } \\
\text { higher }^{*}\end{array}$ & $0^{\mathrm{a}}$ & & & \\
\hline \multicolumn{5}{|l|}{ Working status $\left(D_{3}\right)$} \\
\hline Employed & .490 & 1.632 & .0014 & .000 \\
\hline Unemployed $\left.{ }^{\star}\right)$ & $0^{\mathrm{a}}$ & & & \\
\hline \multicolumn{5}{|c|}{ Household head smoking status $\left(D_{4}\right)$} \\
\hline Smoking & .013 & 1.013 & .0013 & .000 \\
\hline Not smoking*) & $0^{a}$ & & & \\
\hline \multicolumn{5}{|l|}{$\begin{array}{l}\text { Education level of Household head } \\
\left(D_{5}\right)\end{array}$} \\
\hline Not in school yet & .082 & 1.086 & .0025 & .000 \\
\hline Not complete elementary school & 147 & 1.158 & .0018 & .000 \\
\hline Completed elementary school & .100 & 1.105 & .0015 & .000 \\
\hline Completed junior high school & .087 & 1.091 & .0018 & .000 \\
\hline $\begin{array}{l}\text { Completed senior high school or } \\
\text { higher*) }^{*}\end{array}$ & $0^{\mathrm{a}}$ & & & \\
\hline
\end{tabular}

The Negative Binomial model is as follows:

$$
\begin{array}{r}
\hat{\mu}=\exp \left(-0.423+0.224 X+0.127 D_{11}+0.408 D_{21}+0.254 D_{22}+0.108 D_{23}-0.026 D_{24}\right. \\
\left.+0.490 D_{31}+0.013 D_{41}+0.082 D_{51}+0.147 D_{52}+0.100 D_{53}+0.087 D_{54}\right)
\end{array}
$$

Negative binomial regression is more suitable for modeling the variables affecting male adolescent smoking behavior because of Poisson regression's overdispersion. It is indicated by the value of $\mathrm{AIC}$ and $\mathrm{BIC}$ for Negative Binomial regression is smaller than Poisson regression.

Based on Negative Binomial regression, as male adolescent gets older, the number of cigarettes consumed will increase about 1.251 times. Male adolescents who lived in 
the rural area (RR: 1.135), not in school yet (RR: 1.504), already working (RR: 1.632), lived with a household head who is a smoker (RR: 1.013), and also have not completed elementary school (RR: 1.158) have a risk to consume more cigarettes.

\subsection{Discussion}

The result shows that in 2018 , more than $50 \%$ of male adolescent smokers aged 10 18 in Indonesia were light smokers who consumed 1-24 cigarettes a week. The characteristics of male adolescents (age, location of residence, education level, and working status) and the characteristics of household head (smoking status and education level) significantly affect the smoking behavior of male adolescents in Indonesia in 2018 based on the number of cigarette consumption.

The number of cigarettes consumed by male adolescents increases with age. According to Hwang and Park (2014), the earlier adolescents smoke, the more likely they will become regular, daily, and heavy smokers. Male adolescents who smoke earlier will become addicted and start frequently smoking when they get old, so that the number of cigarette consumption will increase.

As a male adolescent gets older, their peers are increasing and can influence their smoking behavior (Kusumawardani et al., 2018). Peers are a significant factor for male adolescents to smoke (Naing et al., 2004). More often, male adolescents see and are exposed to secondhand smoke by their peers, and then there is a possibility that it can increase their smoking behavior.

Male adolescents who live in rural areas have a higher number of cigarette consumption than urban areas. It is in line with research resulting that cigarette and other tobacco consumption in rural areas are higher than in urban areas (Pesko \& Robarts, 2017). This result is also in line with research resulting in one factor influencing young men's smoking behavior in rural areas is education level (Efendi et al., 2019).

Low education level causes villagers are underprivileged to understand the dangers of smoking. They have limited knowledge about the health hazards caused by smoking and the effects on both active and passive smokers (Wang et al., 2014). Therefore, the need for socialization in rural areas about the dangers of smoking prevents and reduces smoking behavior in male adolescents.

Smoking behavior of male adolescents has an inverse relationship with education level. It means the higher the education level, the lower tendency of male adolescents to smoke, causing the number of cigarette consumption to decrease. This result is in line with research resulting that a higher level of education will increase the probability of not consuming cigarettes (Robinson \& Arsani, 2020). A person with a low level of education has less ability to understand the dangers of smoking for health (Efendi et al., 2019). It causes the probability of male adolescents who have low education levels to become smokers and consume cigarettes more than higher education levels.

Male adolescents who are already working and have their income can be easier to buy cigarettes so that their cigarette consumption is more than those who are not working. This result is in line with research resulting that cigarette consumption for someone already working is more than for someone who is not working or has a job 
(Wulandari et al., 2017). Working young men get less supervision from their parents and more often with their peers (Efendi et al., 2019). It can increase the probability of workers to consume more cigarettes.

Other than that, whether or not there are rules that restrict workers from smoking has a close relationship with their smoking behavior (Ham et al., 2011). The absence of regulations to limit male adolescent workers from smoking causes them to be freer to smoke, so that the number of cigarette consumption will increase.

The household head is a person who is responsible for daily needs in a household. Based on 2018 Riskesdas, more than $60 \%$ of male adolescents live with a household head who is the parent who smokes. The probability of adolescent smoking, the number of cigarette consumption, and the type of cigarette smoked are near related to adults' smoking behavior inside the house (Geckova et al., 2002).

Adolescents who live with their parents, who are smokers and are frequently exposed to secondhand smoke in their house, tend to become active smokers. They want to be seen as an adult as their parent so that they start to learn of smoking behavior their parent. The most powerful influence is when parents were heavy smokers, so there is a possibility that the children will follow their smoking behavior so that the children will become heavy smokers (Sutha, 2016). Their father's smoking behavior is more influence on the smoking behavior of male adolescents than females (Alves et al., 2017). So, when male adolescents live with a smoker father, there is a possibility they will become heavy smokers and consume more cigarettes than those who live with a non-smoker father.

The household head's education level also influences the number of cigarette consumption by male adolescents. It is in line with the research carried out by (Geckova et al., 2002) that parental education affects adolescents' smoking behavior. The lower level of parental education will increase the smoking behavior of adolescents. Parents with high education levels will consume cigarettes lower than a parent with a low education level because of the higher education level, the more knowledge about the dangers of smoking (Andrade et al., 2017). It causes parents to possibly restrict male adolescents to smoke to decrease the number of cigarette consumption.

\section{Conclusion and Recommendation}

In 2018, there were 12,153 male adolescent smokers of 10-18 years in Indonesia, with more than half of them were light smokers. Heavy smokers were dominated by older age, living in a rural area, poorly educated, employed, lived with a household head who was a smoker, and had low education. Age, location of residence, education level, employment status, smoking status, and household head education level significantly affect male adolescents' smoking behavior in Indonesia in 2018. Governments need to socialize about the dangers of cigarettes and the formation of the no-smoking area and prohibition and penalties to prevent male adolescents from smoking. Moreover, the parent's role is necessary to avoid smoking around adolescents and pay more attention to their associations.

Acknowledge. The authors thank Politeknik Statistika STIS for all the support. 


\section{Daftar Pustaka}

Agresti, A. (2018). An introduction to categorical data analysis. John Wiley \& Sons.

Alves, J., Perelman, J., Soto-Rojas, V., Richter, M., Rimpelä, A., Loureiro, I., ... Lorant, V. (2017). The role of parental smoking on adolescent smoking and its social patterning: a cross-sectional survey in six European cities. Journal of Public Health, 39(2): 339-346.

Andrade, R. C. C. de, Ferreira, A. D., Ramos, D., Ramos, E. M. C., Scarabottolo, C. C., Saraiva, B. T. C., ... Christofaro, D. G. D. (2017). Smoking among adolescents is associated with their own characteristics and with parental smoking: crosssectional study. Sao Paulo Medical Journal, 135(6): 561-567.

BPPK, B. P. dan P. K.-. (2014). Bunga Rampai: Fakta Tembakau dan Permasalahannya di Indonesia. Retrieved from http://www.tcsc-indonesia.org/wpcontent/uploads/2016/06/Buku-Fakta-Tembakau-2014_Web-Version.pdf

BPPK, B. P. dan P. K.-. (2016). Laporan Survei Indikator Kesehatan Nasional (Sirkesnas). Retrieved from http://labmandat.litbang.kemkes.go.id/riset-badanlitbangkes/menu-riskesnas/menu-rikus/422-sirk-2016

Cahyo, K., Wigati, P. A., \& Shaluhiyah, Z. (2012). Rokok, pola pemasaran dan perilaku merokok siswa SMA/sederajat di Kota Semarang. Media Kesehatan Masyarakat Indonesia, 11(1): 75-85.

Efendi, F., Aidah, F. N., Has, E. M. M., Lindayani, L., \& Reisenhofer, S. (2019). Determinants of smoking behavior among young males in rural Indonesia. International Journal of Adolescent Medicine and Health, 1(ahead-of-print).

Geckova, A., Van Dijk, J., van Ittersum-Gritter, T., Groothoff, J., \& Post, D. (2002). Determinants of adolescents' smoking behaviour: a literature review. Central European Journal of Public Health, 10(3): 79.

Ham, D. C., Przybeck, T., Strickland, J. R., Luke, D. A., Bierut, L. J., \& Evanoff, B. A. (2011). Occupation and workplace policies predict smoking behaviors: analysis of national data from the current population survey. Journal of Occupational and Environmental Medicine/American College of Occupational and Environmental Medicine, 53(11): 1337.

Hardin, J. W., Hardin, J. W., Hilbe, J. M., \& Hilbe, J. (2007). Generalized linear models and extensions. Stata press.

Hilbe, J. M. (2011). Negative binomial regression. Cambridge University Press.

Hwang, J. H., \& Park, S.-W. (2014). Age at smoking initiation and subsequent smoking among Korean adolescent smokers. Journal of Preventive Medicine and Public Health, 47(5): 266.

Kemenkes. (2013). Generasi Muda Sehat, Generasi Tanpa Rokok. Retrieved from https://www.kemkes.go.id/development/site/jkn/index.php?cid=2316\&id=generasimuda-sehat-generasi-tanpa-rokok.htm

Kemenkes. (2015). Perilaku Merokok Indonesia Berdasarkan Riskesdas 2007 dan 2013. Retrieved from https://www.kemkes.go.id/download.php?file=download/pusdatin/infodatin/infodati n-hari-tanpa-tembakau-sedunia.pdf 
Komasari, D., \& Helmi, A. F. (2000). Faktor-faktor penyebab perilaku merokok pada remaja. Jurnal Psikologi, 27(1): 37-47.

Kusumawardani, N., Tarigan, I., Suparmi, et al., \& Schlotheuber, A. (2018). Socioeconomic, demographic and geographic correlates of cigarette smoking among Indonesian adolescents: results from the 2013 Indonesian Basic Health Research (RISKESDAS) survey. Global Health Action, 11(sup1): 54-62.

Montgomery, D. C., Peck, E. A., \& Vining, G. G. (2012). Introduction to linear regression analysis (Vol. 821). John Wiley \& Sons.

Naing, N. N., Ahmad, Z., Musa, R., Hamid, F. R. A., Ghazali, H., \& Bakar, M. H. A. (2004). Factors related to smoking habits of male adolescents. Tobacco Induced Diseases, 2(3): 133.

Pesko, M. F., \& Robarts, A. M. (2017). Adolescent tobacco use in urban versus rural areas of the United States: the influence of tobacco control policy environments. Journal of Adolescent Health, 61(1): 70-76.

Robinson, P., \& Arsani, A. M. (2020). Pengaruh Tingkat Pendidikan Tingkat Kesejahteraan dan Penghasilan terhadap Konsumsi Rokok Harian dari Penduduk Dewasa di Indonesia Tahun 2015. Bappenas Working Papers, 3(1): 75-87.

Sirait, A. M., Pradono, Y., \& Toruan, I. L. (2002). Perilaku merokok di Indonesia. Buletin Penelitian Kesehatan, 30(3).

Suhta, D. W. (2018). Pengetahuan dan Perilaku Merokok Pelajar Sekolah Menengah Pertama. Jurnal Manajemen Kesehatan Yayasan RS. Dr. Soetomo, 4(1): 47-60.

Sutha, D. W. (2016). Analisis Lingkungan Sosial Terhadap Perilaku Merokok Remaja di Kecamatan Pangarengan Kabupaten Sampang Madura. Jurnal Manajemen Kesehatan Yayasan RS. Dr. Soetomo, 2(1): 43-59.

Tristanti, I. (2016). Remaja dan perilaku Merokok.

Utami, T. W. (2013). Analisis Regresi Binomial Negatif untuk Mengatasi Overdispersion Regresi Poisson pada Kasus Demam Berdarah Dengue. Jurnal Statistika Universitas Muhammadiyah Semarang, 1(2).

Wang, J., Li, C., Jia, C., Liu, Y., Liu, J., Yan, X., \& Fang, Y. (2014). Smoking, smoking cessation and tobacco control in rural China: a qualitative study in Shandong Province. BMC Public Health, 14(1): 916.

Wijayanti, E., \& Dewi, C. (2017). Faktor-faktor yang Berhubungan dengan perilaku merokok pada remaja Kampung Bojong Rawalele, Jatimakmur, Bekasi. Global Medical \& Health Communication, 5(3): 194-198.

Wulandari, W., Tedra, W. T., Rizki, I. M., \& Prariesa, D. (2017). Konsumsi Rokok Masyarakat Kota Bandung Tahun 2015 dengan Model Hurdle Negatif Binomial (Hurdle-Nb). Jurnal Aplikasi Statistika \& Komputasi Statistik, 9(2): 19-28.

Yandira, W. \& P., D. (2019). Pemodelan Regresi Poisson pada Data Kematian Maternal di Provinsi Sumatera Barat. Prosiding Seminar Nasional STKIP PGRI Sumatera Barat, 5, 18-26. Retrieved from http://econference.stkip-pgrisumbar.ac.id/index.php/matematika/IPME/paper/viewFile/681/220 